DOI: http://dx.doi.org/10.5007/1980-3532.2015n13p111

\title{
A narrativa ficcional como método no ensino de sociologia
}

\author{
The fictional narrative as a method in the sociology teaching
}

\author{
Gustavo Oliveira Wolf Cavalcante \\ Graduado em Ciências Sociais pela Universidade Federal de Santa Catarina \\ guto7wolf@gmail.com
}

\begin{abstract}
Resumo: Este trabalho reflete sobre o recurso à ficção como estratégia de ensino de sociologia, a partir de experiência de estágio de docência realizada em 2014 no Colégio de Aplicação da Universidade Federal de Santa Catarina. No exercício intitulado "conto sociológico", alguns textos remetiam à concepções que contradiziam o retorno dado pelos alunos nos debates em sala, o que nos deu mostras de que a sociologia pode não lograr êxito em abalar estruturas de pensamento. Supondo uma relação entre esta esterilidade e a sua forma científica, o estudo se debruça sobre possibilidades de desenvolver o pensamento sociológico e agregar capital simbólico a partir da escrita, com a pretensão de empoderar estudantes e compensar desigualdades linguísticas, valendo-se da mimesis artística e da narrativa ficcional para criar um espaço de crítica das representações hegemônicas, de práticas discursivas que contribuam para atenuar a violência simbólica a que são submetidos os alunos do ensino médio ao se depararem com a aridez e a objetividade da linguagem científica.
\end{abstract}

Palavras-chave: Sociologia; Educação; Linguagem; Ficção; Mimesis.

\begin{abstract}
This work reflects on the use of fiction as a strategy for teaching sociology, from a teaching internship experience held in 2014 in the Application School of the Federal University of Santa Catarina. In the performance entitled "Sociological Story", some texts referred to conceptions that contradicted the feedback given by students in classroom discussions, which has shown that sociology may not succeed undermining some thought structures. Assuming a relationship between this sterility and its scientific form, the study looks at possibilities to develop the sociological thought and add symbolic capital from the writing, with the intention of empowering students and compensate linguistic inequality, taking advantage of the mimesis art and the fictional narrative to create a space for criticism about hegemonic representations, and also discursive practices that contribute to lessen the symbolic violence to which the high school students are subjected when they come across the aridity and the objectivity of scientific language.
\end{abstract}

Keywords: Sociology; Education; Language; Fiction; Mimesis.

Originais recebidos em: 29/02/2016

Aceito para publicação em: 15/06/2016

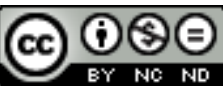

Este trabalho está licenciado sob uma Licença Creative Commons Atribuição-Uso NãoComercial-Vedada a criação de obras derivadas 3.0 Unported License. 


\section{Introdução}

Os tempos de escola me remetem à falta de estímulos para o uso da imaginação, às poucas oportunidades de exercê-la e de aprender com ela, e creio que ainda hoje o que impera no ensino é a reprodução, que gera um alheamento entre estudante e estudo. Novas ideias e pensamentos são suscitados pelos conteúdos trabalhados em sala e é a partir da imaginação que eles são testados e integrados à vida, o momento em que se toma o saber para si, ressignificando-o e sedimentando o aprendizado. A curiosidade e as inquietações que trazem um jovem à sociologia e a expansão do olhar sobre o mundo que ela provoca necessitam de um escape, uma vazão maior do que a permitida pela linguagem escolar, não somente pela liberdade da expressão, mas, como se quer aqui discutir, pelo ganho pedagógico do exercício da escrita em um âmbito mais amplo, menos apegado às noções científicas de verdade, herméticas, impermeáveis, cedendo espaço para a construção de representações dos contextos problematizados pelas aulas.

Durante a disciplina de Estágio Supervisionado em Ciências Sociais II, cursada na Universidade Federal de Santa Catarina, eu tive a oportunidade de realizar novamente uma ideia que teve início com a minha experiência na escola Leonor de Barros, em 2012, enquanto bolsista do PIBID - Programa Institucional de Bolsa de Iniciação à Docência; uma atividade a que chamei "conto sociológico", e que visa criar um lugar onde os alunos possam se apropriar dos conceitos e saberes desenvolvidos nas aulas de sociologia expressando suas reflexões em linguagem ficcional. A proposta traz elementos norteadores da narrativa, de modo a estabelecer um ponto de partida comum que engendre a relação com a temática, além de especificadas as descrições que o texto deve contemplar. Acredito ser compatível com temas diversos e, quando da minha regência durante o estágio, obedecendo à programação para o segundo ano, a atividade foi desenvolvida a partir das aulas sobre Bourdieu, no que concerne à sua expansão do conceito de capital e à crítica ao caráter conservador da escola. Segue a descrição da atividade do plano de aulas.

Considerando a aula sobre o sociólogo Pierre Bourdieu e os conceitos de capital cultural e social desenvolvidos pelo autor, escreva uma história curta sobre um (a) jovem que acabou de concluir o ensino médio e deve decidir sobre seu futuro profissional. O texto é livre para ter cunho autobiográfico e/ou ficcional. Deve-se descrever a personagem quanto à origem social, os gostos e as preferências culturais, os sonhos e as perspectivas. A metáfora sugerida como ponto de partida para o conto é o trajeto de ida para o trabalho, ou 
faculdade, no qual a personagem reflete sobre a sua condição atual enquanto projeta-se para o futuro, literalmente caminhando para o amanhã.

Depois, deve-se dar continuidade à história. A personagem agora está na faixa dos quarenta anos e o momento a ser narrado é o do retorno de seu trabalho para casa. As descrições devem ser atualizadas e o aluno precisa dizer o que mudou na vida da personagem, se ela realizou ou não suas aspirações e, se possível, quais as estratégias utilizadas por ela na disputa por uma posição social. O critério para a avaliação dos textos será, conforme Bourdieu, a coesão entre os capitais de que a personagem detinha quando jovem e os que ela possui na fase adulta, com as devidas explicações para possíveis "saltos", ou seja, quando a figura consegue ter êxito em superar-se, em ir além do que fora "destinado" pela sua herança cultural.

Aula expositiva, texto, imagem e vídeo aparentemente deram substância às discussões sobre a questão da meritocracia, depois, porém, todo este saber parecia algo alheio em muitas narrativas, e algumas noções manifestas articulavam-se como se nunca houvessem se defrontado com a sociologia, o que nos levou a crer que o alcance e, consequentemente, o acesso à disciplina seja limitado pela sua forma científica, e que quando é livre a voz própria, outras verdades podem emergir. Tal debilidade no ensino, a defasagem de capitais, como também as possibilidades de compensá-las através da escrita ficcional estruturam a nossa hipótese de que tornar a sociologia mais permeável ao indivíduo pode contribuir para que este seja permeado pela sociologia.

\section{O pensamento sociológico e o texto ficcional}

Em "O ensaio como forma", presente na coletânea "Notas de literatura I", Adorno discorre sobre a importância da forma, a qual remete à retórica presente na oralidade, contudo suprimida na lógica discursiva, sendo o arranjo do texto considerado como atributo meramente acidental. "A palavra lançada irresponsavelmente pretende em vão provar sua responsabilidade no assunto, e a reflexão sobre as coisas do espírito torna-se privilégio dos desprovidos de espírito" (ADORNO, 2003, p.19). Podemos relacionar os postulados do autor em defesa do ensaio com as nossas premissas a favor do texto ficcional e a ideia de que os moldes nos quais se insere a escrita qualificam o pensamento e, tratando-se da escola, o aprendizado:

Escreve ensaisticamente quem compõe experimentando; quem vira e revira o seu objeto, quem o questiona e o apalpa, quem o prova e o submete à reflexão; quem o ataca de diversos lados e reúne no olhar de seu espírito aquilo que vê, pondo em palavras o que o objeto permite vislumbrar sob as condições geradas pelo ato de escrever (ADORNO, 2003, p.35-36). 
Carecemos de um esforço no sentido de enriquecer a escrita, de permitir, como fazia Paulo Freire, que os estudantes se apropriem dos conhecimentos escolares utilizando as suas próprias categorias, sua língua, suas experiências, seu imaginário, (FREIRE, 2011) pois, se há uma má formação nos estudos literários, acredito que a escola deva auxiliar o aluno a estabelecer conexões e pontes, promovendo o desenvolvimento da escrita a partir do meio linguístico de origem. Para compensar a defasagem dos estudantes que têm restrições no acesso ao que Bourdieu referiu-se como "cultura livre" - neste caso, especificamente o incentivo ao gosto pelos livros e pela literatura - e que, portanto, apresentam limitações para escrever, pode-se soltar as amarras da escrita, pois esta parece crescer-lhes como que dentro de uma armadura pesada e pragmática, subordinada ao imperativo da linguagem escolar/científica, impelida a dissertar sempre objetivamente, a reproduzir saberes estranhos, copiando e colando, sem nunca experimentar o prazer de escrever.

\footnotetext{
O paradigma que aqui proponho não segue a partilha das funções; não visa a colocar de um lado os cientistas, os pesquisadores, e de outro os escritores, os ensaístas; ele sugere, pelo contrário, que a escritura se encontra em toda parte onde as palavras têm sabor (saber e sabor têm, em latim, a mesma etimologia). [...] Na ordem do saber, para que as coisas se tornem o que são, o que foram, é necessário esse ingrediente, o sal das palavras. É esse gosto das palavras que faz o saber profundo, fecundo (BARTHES, 1978, p. 21).
}

Pretendo aqui analisar o uso da escrita ficcional no ensino de sociologia para atenuar a violência simbólica inerente ao processo educativo, para ampliar as possibilidades do aluno de ativar e manipular esse conhecimento, e não simplesmente por mais liberdade, mas também, devido à peculiaridade da disciplina, para consagrarlhes humanidade face ao objeto de estudo. Tratando-se de questões sociais, vemos como fundamental a prática de se colocar no lugar do outro, de se posicionar enquanto sujeito diretamente envolvido pelos temas e conceitos trabalhados em sala, no sentido de confrontar esse alheamento próprio do olhar científico. Indo além do que Wright Mills pretendia com a "Imaginação Sociológica" (1972), para ampliar a noção do estudante quanto à complexa gama de relações sociais, parece-me imprescindível o exercício da alteridade. Ao estudar as contradições da sociedade, a desigualdade e o horror do poder, enfim, ao abordar questões humanas, deve-se estar apto não só a pensar logicamente, mas a sentir.

A única potência literária que faz tremer todas as autoridades injustas é a eloquência generosa, é a filosofia independente, que julga no tribunal do 
pensamento todas as instituições e todas as opiniões humanas. 'Eis explicitadas a eloquência e a filosofia literárias'; generosa a primeira, independente a segunda, que têm por traço comum conciliar a razão antes com a capacidade de comover do que com a lógica do cálculo. [...] A literatura é movida pela imaginação quando dotada da capacidade de 'comover', de conduzir o receptor a questionar emocionalmente as instituições sociais que o acompanham (LIMA, 2006, p.328).

Modelo "recomendado" pelo imperialismo norte-americano, a ideia de uma educação técnica, introduzida durante a ditadura militar, é muito pobre frente à complexidade do ser social. Visando apenas a vida profissional, ensina conceitos muitas vezes indiferentes à realidade de quem aprende e que se restringem ao desenvolvimento de uma inteligência adequada ao trabalho. Com base em Arturo Escobar e o seu conceito de "sentipensar", entendo que a educação deva estar comprometida com o contexto e com a integralidade das inteligências lógica e discursiva (ESCOBAR, 2014, p. 16).

A literatura ou, mais especificamente, a ficção literária, pode servir de aporte discursivo na aprendizagem sociológica para preencher o hiato entre a abordagem científica e a vida cotidiana, isto é, oferecendo condições para que os estudantes assimilem e interajam essas duas linguagens por meio de uma terceira, a ficcional, de modo a enriquecer a perspectiva sobre ambas as dimensões, conceitual e real, ao viabilizar a construção de conexões específicas, porque permeadas por experiências próprias, e íntimas, através da imaginação, rompendo a assepsia da ciência para tocar, ou permitir ser tocada, seja pelas manifestações da cultura, seja pela miséria humana.

A literatura assume muitos saberes. [...] Se, por não sei que excesso de socialismo ou de barbárie, todas as nossas disciplinas devessem ser expulsas do ensino, exceto numa, é a disciplina literária que devia ser salva, pois todas as ciências estão presentes no monumento literário. É nesse sentido que se pode dizer que a literatura, quaisquer que sejam as escolas em nome das quais ela se declara, é absolutamente, categoricamente realista: ela é a realidade, isto é, o próprio fulgor do real. Entretanto, e nisso verdadeiramente enciclopédica, a literatura faz girar os saberes, não fixa, não fetichiza nenhum deles; ela lhes dá um lugar indireto, e esse indireto é precioso. Por um lado, ele permite designar saberes possíveis - insuspeitos, irrealizados: a literatura trabalha nos interstícios da ciência [...] A ciência é grosseira, a vida é sutil, e é para corrigir essa distância que a literatura nos importa. Por outro lado, o saber que ela mobiliza nunca é inteiro nem derradeiro: a literatura não diz que sabe alguma coisa, mas que sabe de alguma coisa; ou melhor: que ela sabe algo das coisas - que sabe muito sobre os homens (BARTHES, 1978, p.1819).

\section{Sociologia e mimesis}

Revista Em Debate (UFSC), Florianópolis, volume 13, p. 111-131, 2015. ISSNe 1980-3532 
O que a sociologia procura esclarecer através de conceitos a mimesis representa artisticamente, pois é ela, por excelência, o meio por onde se realiza a capacidade crítica da arte. Daí o interesse de Costa Lima em estudar a trajetória incerta do conceito grego, que está relacionada ao espaço concedido ao gênero poético. $\mathrm{Na}$ escrita da história, como se percebe em Virgílio, passou-se a dar destaque às ações políticas e militares, objetivas e comprováveis, numa linguagem pragmática no tratamento dos fatos, para transparecer nada mais que impessoalidade, esforçando-se em prescindir de um estilo e em apagar quaisquer vestígios do contexto a partir do qual se recria o passado.

Restritos à categoria de enfeite, o discurso poético e o ficcional foram apartados da conversa de gente grande, sob a alegação de não contribuírem para o pensamento e iludirem com fantasias que nada ensinam, significando apenas obstáculos adornados para se alcançar o altar da verdade. Esta deve ser o norte não só da ciência e da filosofia, como também o modelo para que a arte se espelhe, imite e se limite. Para que os adultos não sejam incomodados, o poder e o seu arbitrário são encerrados nessa moldura de verdade absoluta a que arte é obrigada a reificar em suas obras, a permanecer quieta no cercadinho, boazinha, obediente. Sem poder questionar, apertar a massa e remodelar, a mimesis tem seu entusiasmo e sua fúria sufocados por uma noção hegemônica de realidade, por ser conduzida através dos séculos a brincar tão somente do jeito que a imitatio brinca, a se lhe reconhecer como sinônima-irmã.

O discurso sociológico, consideravelmente mais jovem, partilha dessa impulsão da mimesis por desconstruir a verdade, desmistificar realidades, mas, no momento em que busca legitimar o seu discurso enquanto ciência da sociedade, a sociologia reserva um espaço para si e se autoriza a eleger suas próprias verdades; estaria ela isenta de se fechar em si mesma? Em que medida ela é capaz de olhar para o lugar de onde fala?

\footnotetext{
Para que a autonomização de uma atividade discursiva seja procedente será preciso que se faça segundo coordenadas que justifiquem outras autonomizações. Do contrário, teremos a legitimação de um único modo discursivo e menos graus de tolerância para os demais. É essa exatamente a situação na abertura dos tempos modernos: o critério ortodoxo da verdade não admite que o discurso poético exista senão sob o império do ornato (LIMA, 1995, p. 92).
}

Por mais que se trabalhe a dinâmica entre tais conceitos nas aulas de sociologia, é a mimesis que tem mais capacidade de comportar agência e estrutura, pois a partir dela o sujeito engendra uma reconfiguração do real, jogando com determinados aspectos e 
valores da vida social, de modo a escavá-los, retirando-os de seu contexto, revirando e revelando suas contradições, sem que tal reconstrução pretenda ser científica, universal; pelo contrário, ressalta-se sua particularidade, o diálogo desta com as noções estabelecidas a que está exposta. Para alunos do ensino médio, a sociologia pode soar por demais abstrata, e até a graduação, ou, de fato, o doutorado, não se pode falar por ela ou tomá-la para si: não é qualquer um que consegue se comunicar através dela, dominar sua linguagem, seus códigos e beber um pouco de sua legitimidade.

Acredito que a sociologia, nas diversas áreas em que se debruça, e aqui especialmente a sociologia oferecida pela escola, deva estar aberta a outras formas discursivas, a aprender e também a ensinar com elas. Pois parece no mínimo potente a combinação de estratégias - a problematização de um tema pela sociologia, a elasticidade e a brecha à imaginação concedidas pela ficção, orientadas pela mimesis a fazer correspondências intencionais numa recriação, numa obra, por fim revisitada pela análise sociológica - para armar o estudante de dispositivos discursivos e sensibilidade para compreender o caráter relativo das representações hegemônicas e transgredir seus significados.

O princípio da imitatio, que Luiz Costa Lima busca desvencilhar do conceito de mimesis, é análogo ao modelo de aprendizagem vigente, em que se espera que o aluno reproduza bem, decore, copie e cole os saberes a que lhes são transmitidos, enquanto, pela ação da mímesis, ele manipula símbolos, valores e costumes sociais para engendrar sua própria reconfiguração do mundo, que faz subjazer nesses arranjos o seu mundo particular: "O falar sobre o mundo é também o falar sobre si" (LIMA, 2006, p. 112). Em vez de ensinar aos jovens idolatrar uma versão acabada de verdade, construção da qual eles não participam, sugere-se que a verdade seja despida de sua aporia, que se desconfie de sua postura rígida e impecável, indagando-lhe os interesses e os interessados. Pela amplitude discursiva da ficção e pela representação mimética, a verdade pode, por exemplo, ser caricaturada para que o seu exagero diga o que ela não consegue, ou não quer dizer. Permeada pelo sujeito, pelo tempo histórico e o discurso, a verdade deve ser desmontada e reconstruída segundo o ponto de vista.

O monopólio na modernidade do discurso científico pressupunha que a realidade é uma e, portanto, só uma modalidade de tratar dela seria legítima. Procurar, ao contrário, um leque de possibilidades discursivas significa que entendemos a realidade como múltipla e composta de tempos diversos (Herder), produto da fusão de uma materialidade com um 'ponto de vista' 
(Simmel), não mais a confundindo com um mero 'está aí', pronto e dócil para ser descrito e dominado (LIMA, 2006, p. 385-386).

Se "a realidade significa simplesmente a relação com nossa vida emocional e ativa" (LIMA, 2006, p. 23) e a sociologia intenta desnaturalizar representações disseminadas e noções arraigadas que carregam e exercem poder porque se impõem como universais, ocultando sua parcialidade, como não dar espaço e protagonismo às experiências individuais - pois se pensamos e agimos é por meio da relação destas com as experiências coletivas, sendo a nossa prática uma interpretação destilada desse condicionamento mútuo - na formação de um pensamento crítico?

Falar em expansão da envergadura discursiva da sociologia, no contexto escolar, é pretender que ela seja porosa a outros gêneros que, por sua condição menos submissa à ideia abstrata e supostamente coletiva de realidade, emprestam-lhe um pouco de sua flexibilidade para abarcar reflexões despojadas de impessoalidade, da objetiva aparência de imparcialidade, ideias e cogitações que surgem da escrita ficcional e são por ela envolvidas, que, por menos fecundas que sejam, são filhas não simplesmente de uma mentira ou de um engano, como acusa a verdade científica, mas também de uma criação. A palavra "invenção" guarda o duplo sentido (LIMA, 2006, p. 238). Ficções inventadas para contrapor o pensamento às ficções estabelecidas e bem fundadas. Ficções preocupadas em experimentar a sociedade, mobilizadas pelo olhar sociológico, sensível e subjetivo para ser denso, obras da mimesis, traços de realidade intencionalmente indicados (LIMA, 2006, p. 200), "correspondência confrontativa", enfim, um exercício discursivo e cognitivo, mas também uma aprendizagem tocante: "pois a surpresa e mesmo o horror reservados a essa exploração do subsolo implicam uma carga emocional que se agrega à compreensão que se alcance” (LIMA, 2006, p. 207).

\section{Ficções Sociais}

A fé nos objetivos, no esforço pessoal, a cultura dominante, a manutenção das condutas, são todas construções sociais - aprendizado fundamental das ciências sociais: tudo é construído, nossas crenças não são mais que ficções, ilusões não admitidas, pretensas verdades a serviço da estabilidade das instituições e da coesão da sociedade. Ideias sutilmente enganosas, mas imprescindíveis para a reprodução tranquila da 
estrutura social, dogmas materializados pela crença geral, religião da ordem que serve a deuses e interesses obscuros, a forças invisíveis e onipresentes, numa palavra, simbólicas.

O poder simbólico é um poder de construção da realidade que tende a estabelecer uma ordem gnoseológica: o sentido imediato do mundo (e, em particular, do mundo social) supõe aquilo a que Durkheim chama o conformismo lógico, quer dizer, 'uma concepção homogênea do tempo, do espaço, do número, da causa, que torna possível a concordância entre as inteligências'. Durkheim - ou, depois dele, Radcliffe-Brown, que faz assentar a 'solidariedade social' no fato de participar num sistema simbólico - tem o mérito de designar explicitamente a função social (no sentido de estruturofuncionalismo) do simbolismo, autêntica função política que não se reduz à função de comunicação dos estruturalistas. Os símbolos são os instrumentos por excelência da 'integração social': enquanto instrumentos de conhecimento e de comunicação [...], eles tornam possível o consensus acerca do sentido do mundo social que contribui fundamentalmente para a reprodução da ordem social: a integração 'lógica' é a condição da integração 'moral' (BOURDIEU, 1989, p.9-10).

A sociologia é a ciência que se intromete entre a camada social e o sentido que a reveste - uma rede simbólica de funções e missões sociais -, descolando a partir de suas análises o que parece ser naturalmente justaposto, sedimentado, para fazer notar que o seu objeto não é uno, que os laços entre indivíduos e estrutura são aparatos simbólicos preenchendo um verdadeiro vácuo.

As funções sociais são ficções sociais. E os ritos de instituição 'fazem' aqueles que instituem o rei, cavaleiro, padre ou professor, forjando sua imagem social, confeccionando a representação que ele pode e deve fazer-se enquanto pessoa moral, ou seja, enquanto plenipotenciário, mandatário ou porta-voz de um grupo. Mas também o fazem num outro sentido. Impondolhe um nome, um título, que o define, o institui, o constitui, o intima a tornarse o que é, ou seja, o que ele tem de ser, obrigam-no a 'cumprir' sua função, a entrar no jogo, na ficção (BOURDIEU, 1994, p.54-55).

A ficção intencional, que se constrói e se reconhece enquanto ficção, tem o potencial transgressor para solver o verniz de verdade das ficções sociais. Porque sua consistência é semelhante - embora a sua cola seja maleável -, a ficção permite que se estabeleçam novas colagens, as quais "des-sacralizam", recortam a aura das tradições e valores para nela figurarem sob outra forma, retirando-lhes levemente a aderência social, revelando a artificialidade de seu grude:

A ficção literária se distingue daquelas que fundam o 'estabelecimento de instituições, sociedades e imagens do mundo' porque, ao contrário destas, supõe que 'desnuda a sua ficcionalidade'. Entendemos esse desnudamento como a tendência que a ficção literária apresenta de se expor, não como um 
simulacro da realidade, mas como uma apresentação desta, muitas vezes desmistificante (LIMA, 2006, p. 289).

A razão científica que conquistou das mãos religiosas o monopólio do discurso que inaugura o mundo, na modernidade converteu-se em forma de controle. "Suponho que toda a disciplina, como Nietzsche claramente observou, é constituída por aquilo que ela proíbe os seus praticantes de fazer [...] por um conjunto de restrições ao pensamento e à imaginação [...]" (WHITE, 2001, p. 142). Este poder que a ciência exerce para reproduzir sua legitimidade, negando as demais práticas que não se conformam aos seus métodos, acaba por privá-la de uma parcela imensa de conhecimento humano.

\footnotetext{
Conhecimento científico é expressão que lembra laboratório, instrumental de pesquisa, trabalho programado, metódico, sistemático e não provoca associações com inspiração mística ou artística, religiosa ou poética. A expressão "conhecimento científico" evidencia o caráter de autoridade, de respeitabilidade, que falta ao conhecimento vulgar (RUIZ, 1986, p. 92-93).
}

Tanto a ciência quanto os conhecimentos que ela produz poderão ser estéreis, pois não saber se comunicar com outras configurações, categorias, princípios, é não ter diálogo com outros modos de pensar, isto é, com pessoas. Penso que a experiência do ensino deva elegantemente desrespeitar a autoridade científica e estimular a exploração dos demais saberes. Se a escola é preparatória para o mundo, não deve apostar a formação de cidadãos toda na ciência, pois esta sozinha não é capaz de dar conta da vida. Em Trópicos do Discurso, Hayden White argumenta que, em vez de a ciência tentar escapar do incerto, da penumbra, para repousar no real, no verdadeiro, deveria, ao contrário, tirar proveito desses "desvios", dos significados e das figuras de linguagem que transbordam do uso lógico e disciplinado das palavras.

A ciência social se articula em conceitos, arma-se de dados e toma a bênção científica para afrontar e dominar discursos dominantes, mas em seu logro ela não destrói o poder que combate, refuta-o para tomar-lhe a legitimidade, e vale-se dela para disparar proposições, engessando o seu poder - em tese, portador da virtuosidade de uma missão social - de desconstruir o poder. Seria como uma espécie de socialismo que, ao pretender se apropriar de riquezas há muito concentradas para depois redistribuí-las, tem seus propósitos sabotados por seus meios e acaba, sob novas configurações, encerrando os bens numa elite. A sociologia, tal como as demais ciências, por mais revolucionárias que se queiram, traem-se discretamente ao ambicionar o lugar de verdade. 
[...] se o discurso verdadeiro não é mais, com efeito, desde os gregos, aquele que responde ao desejo ou aquele que exerce o poder, na vontade de verdade, na vontade de dizer esse discurso verdadeiro, o que está em jogo, senão o desejo e o poder? $O$ discurso verdadeiro, que a necessidade de sua forma liberta do desejo e libera do poder, não pode reconhecer a vontade de verdade, essa que se impõe a nós há bastante tempo, é tal que a verdade que ela quer não pode deixar de mascará-la (FOUCAULT, 1996, p. 20).

A ficção arquiteta obras profanadoras cuja estrutura não quer e não pode querer este lugar sagrado de verdade, seu poder é anárquico, mas, se não respeita autoridades e instituições, tampouco é a ausência de princípios - define as próprias regras. No que se dispõe aos alunos, o discurso ficcional permite que arrebatem o poder da crítica sociológica sem a premissa excludente de atender aos pré-requisitos que cercam a disciplina para num salto subverterem as representações hegemônicas, as ficções sociais, e ainda se esquivarem do poder científico que se lhes insinua sua reprodução, conquanto explorando e incorporando seus saberes - uma livre atualização da sociologia através da ficção mimética: afinal, o que importa aqui é o aprendizado, não a consagração da disciplina.

Para efeitos educativos, ao voltar a análise sociológica contra si mesma, ou seja, ao perceber, a partir de seus conceitos, que o acesso a eles é dificultado pela linguagem que a sociologia inventa para exercer e garantir o seu poder, a sua legitimidade, torna-se relevante o desenvolvimento de meios de aproximá-la dos alunos para que dela possam se apropriar, caso se deseje que ela seja, como afirma Bourdieu, uma resistência contra formas de opressão, uma arma de defesa, um "esporte de combate" com o qual enfrentamos os mecanismos de dominação simbólica.

O empreendimento paradoxal que consiste em usar de uma posição de autoridade para dizer com autoridade o que é dizer com autoridade, para dar uma aula, mas uma aula de liberdade a respeito de todas as aulas, seria simplesmente inconsequente, ou mesmo autodestrutivo, se a própria ambição de fazer uma ciência da crença não supusesse a crença na ciência. De qualquer forma, nada é menos cínico, menos maquiavélico, do que esses enunciados paradoxais que enunciam ou denunciam o próprio princípio do poder que exercem. Não haveria sociólogo que assumisse o risco de destruir o discreto véu de fé ou de má-fé que faz o charme de todas as devoções institucionais, sem que ao mesmo tempo acreditasse na possibilidade e necessidade de universalizar a liberdade em relação à instituição que a sociologia procura; sem que acreditasse nas virtudes libertadoras daquilo que é sem dúvida o menos ilegítimo dos poderes simbólicos, o da ciência, especialmente no momento que toma a forma de uma ciência dos poderes simbólicos capaz de restituir aos sujeitos sociais o domínio das falsas transcendências que o desconhecimento não para de criar e recriar (BOURDIEU, 1994, p. 62-63). 
Ciente dos percalços de se tentar reverter esse processo de violência simbólica, da inculcação de noções de mundo "fora de lugar", da ordem das falsas transcendências acima referidas, a partir de uma ciência que empreende outra espécie de violência simbólica, a atuação do professor se dá sobre o espaço entre o que o aluno já sabe e o que ele tem condições de aprender; Vygotsky chamou este "lugar" de zona de desenvolvimento proximal (OLIVEIRA, 1997). No exercício cá proposto, entende-se que o estudante do ensino médio deve ter a imaginação estimulada, pois a partir dela pode conceber realidades, contextos, aos quais não tem acesso imediato, e adquirir saberes que extravasam suas limitações. Enquanto na perspectiva sociológica a escrita ficcional pode abrir caminho para o acúmulo de capital cultural, pedagogicamente, podemos inferir que ela trabalhe no intuito de expandir a zona de desenvolvimento proximal, proporcionando, mediante o incentivo à exploração da linguagem, ferramentas para a interpretação de realidades sociais.

\section{Realidades Inverossímeis}

Depois de versar sobre a importância de se superar, por meio da ficção, a imposição de uma noção de realidade, pareceria incoerente pretender, com as exigências avaliativas, atar os textos dos estudantes a qualquer espécie de realismo. Os nexos requisitados pelo exercício do "conto sociológico", todavia, visavam atentá-los quanto à coesão interna da narrativa de uma personagem jovem, com determinadas expectativas quanto à vida profissional e, depois, a descrição de seu retorno, vinte ou trinta anos mais tarde, as conquistas ou insucessos, sua posição atual na escala social, o que requeria, quando não houvesse uma correspondência entre os capitais de origem dos personagens e aqueles de que dispõem na maturidade, um esclarecimento acerca das estratégias de que se valeram para superar as perspectivas impostas pela ascendência familiar. Não obstante a liberdade de contar sua história como bem entender, o aluno deveria respeitar a estrutura inicial para não perder de vista o norte da narrativa, estabelecido pela relação com a temática da aula de sociologia.

Num texto intitulado "A personagem do romance" (1976), Antonio Candido tece comparações entre vida e literatura, e afirma que a ficção implica uma coerência entre os seus elementos, entre a personagem e o enredo, submetidos à lógica da estrutura, enquanto na vida, devido à sua fluidez, tudo seria praticamente possível. Em nossa 
proposta, procuramos fomentar nos alunos uma associação entre essa necessidade de coesão na narrativa ficcional e a hierarquia, ou o "destino" imposto pela herança de capitais na vida dos indivíduos. Ao nos depararmos nas aulas com a reprodução de convicções de cunho individualista, defensoras da máxima, ou do mito do self-made man, do homem que se faz por si mesmo, concepções estas que a aula sobre Bourdieu visa desconstruir, buscamos, a partir da ficção mimética, dar mais verossimilhança à realidade social, reunindo seus fragmentos e dispondo-os em torno de um sentido estabelecido pela sociologia para tornar mais evidente uma constante social mitificada.

A sociologia desvela a self-deception, a mentira para si mesmo coletivamente empreendida e encorajada e que, em toda a sociedade, está no fundamento dos mais sagrados valores e, portanto, de toda a existência social. Ela ensina, com Marcel Mauss, que 'a sociedade sempre se paga com a falsa moeda de seu sonho' (BOURDIEU, 1994, p. 34).

Curiosamente, estudantes que demonstravam ter compreendido o caráter conservador da escola e a rigidez da ordem social vigente contradiziam as probabilidades ao narrar reviravoltas na vida de seus personagens que, não obstante as dificuldades ou o darwinismo social do sistema capitalista, nunca deixaram de se esforçar, tampouco desistiram de seus sonhos e, por fim, ricos, emplacaram o sucesso. Embora Bourdieu torne o fracasso explicável pelas condições e, sobretudo, pelas disparidades sociais, alguns textos deixaram transparecer uma fé no esforço pessoal, na obstinação, num “final feliz" para aqueles que merecem, que fizeram por merecer, o que praticamente significa supor que a imensa massa de excluídos do sistema capitalista encontra-se nessa condição por não batalhar o suficiente, não se empenhar ao máximo. De acordo com Costa Lima, “[...] É correto mas simplista dizer que os discursos não oferecem os motivos dos que falam. Algumas vezes, seria melhor dizer que é pelos discursos que as pessoas se traem" (LIMA, 2006, p.81). Os trechos a seguir foram selecionados pela incomum similaridade dos relatos:

Uma determinada menina que estudava em um colégio morava em uma família de pessoas muito pobres. Mas ela era muito determinada, ela acordava cedo todos os dias para trabalhar e estudava à tarde e fazia comida, cuidava da casa com sua mãe. [...] Helena é o nome dessa moça. Ela gostaria de exercer a função de médica no futuro e sabia que para isso teria de se esforçar muito. [...] Helena foi ver e quando o viu o tal resultado, viu que tinha sido aprovada. [...] Estavam morando num bairro bom e Helena abriu mais tarde um lugar para ajudar pessoas mais pobres (Estudante M.).

Eduardo era estudante de uma escola pobre [...] sua família era pobre e a renda familiar era de aproximadamente um salário mínimo. Em sua casa 
moravam oito pessoas e não havia cômodos suficientes para todos. Eduardo tinha o sonho de ser médico [...] Na faculdade, Eduardo era um dos melhores, não foi à toa que passou em segundo lugar no vestibular. [...] Finalmente, depois de tanto esforço, e após tantos anos, estágios, projetos, Eduardo se formou [...] passou em $1^{\circ}$ lugar no concurso e atualmente, depois de 45 anos, ele ainda trabalha no mesmo hospital, tem uma vida maravilhosa e sua família é linda (Estudante N. de L.).

Luisa queria se formar em medicina, que é algo incomum para sua classe social [...] negra de origem humilde [...] não sabe se vai conseguir, pois ser de classe baixa e viver na periferia pode muitas vezes significar portas fechadas. [...] Luísa conseguiu se formar em medicina numa faculdade pública, e trabalha em um dos melhores hospitais da cidade, mas não é todo jovem de origem pobre que consegue, mas Luísa nunca deixou isso abalar ela por completo, e conseguiu alcançar seu objetivo (Estudante G.).

Essa fixação pelo acesso ao prestígio da posição social que ocupa um médico, relevando e suavizando os mecanismos de exclusão, essa ficção social consciente ou inconscientemente reunida e reiterada pela ficção mimética num verdadeiro "conto de fadas" reforça nossa hipótese inicial: a sociologia empreendida nas aulas não foi - e arrisco-me a dizer que não é - profunda suficientemente para desorganizar os pressupostos de uma ideologia. Após a aula, tive a sensação de ter conseguido passar elementos essenciais da perspectiva crítica de Bourdieu, de ter cumprido os objetivos propostos, principalmente considerando a postura dos estudantes nos debates gerados pelo aluno P.B. - imprescindível em seu papel de pivô das discussões. Todavia, na semana seguinte, alguns textos desmentiram minhas impressões.

Aqui começa a história de Igor, um menino que, graças a Deus, nunca passou fome, mas cuja família está dentro dos parâmetros, não é nem pobre, nem rica. [...] Igor quer ser jornalista. [...] Ele sabe que essa jornada não será fácil, mas ele está convicto, quer enfrentar todas e quaisquer dificuldades [...] Igor entra na faculdade, claro, de jornalismo e depois de exatamente quatro anos se forma. [...] Dono do jornal mais comercializado da região, Igor, agora com 38 anos, chega a sua casa e todos os dias é recebido com calorosos abraços de sua esposa, que o mima com jantares deliciosos já que é dona de casa e tem tempo livre para experimentar novas receitas (Estudante A.).

A trajetória de Igor, narrada pela estudante A, tem um início ponderado, numa família de classe média e tendo um objetivo não tão distante de suas condições, mas, após algumas ressalvas quanto à determinação da personagem, a autora descreve uma incrível ascensão profissional e encerra seu conto numa imagem romântica que remete à publicidade da década de 1950.

Não que tenham sido exigidas histórias pessimistas, ou fatalistas, mas, aludindo à ideia de que, na ficção, "é preferível o que é impossível mas verossímil ao que é 
possível mas não persuasivo" (LIMA, 1995, p. 81), foi pedido coerência entre os capitais de que dispunha a personagem no começo e os que acumulava no regresso da história, a fim de conduzi-los a um confrontamento das possibilidades reais de êxito possivelmente percebidas através das experiências próprias, ou de pessoas próximas, como também esclarecidas pela aula de sociologia - com os discursos ideológicos com que são bombardeados diariamente, com as construções da narrativa midiática conservadora. Este processo tencionava fazer emergir e dar nitidez à falsa consciência que é engendrada nas classes dominadas pelas dominantes através dos aparatos simbólicos que detêm.

É enquanto instrumentos estruturados e estruturantes de comunicação e de conhecimento que os 'sistemas simbólicos' cumprem a sua função política de instrumentos de imposição ou de legitimação da dominação, que contribuem para assegurar a dominação de uma classe sobre outra (violência simbólica) dando o reforço da sua própria força às relações de força que as fundamentam e contribuindo assim, segundo a expressão de Weber, para a 'domesticação dos dominados' (BOURDIEU, 1989, p.11).

A interpretação dos contos dos alunos, em razão de serem carregados de subjetividades, pode significar uma tarefa trabalhosa e complexa para o professor. Contudo, ao enveredar pelos textos, o docente reúne referências para identificar as doutrinas que escoram determinados discursos, e que se manifestam enquanto interesses, pertenças de classe, de status social (FOUCAULT, 1996, p. 43); assim, penso que ele pode aperfeiçoar suas estratégias, pois tem mais elementos para preparar uma aula adequada ao seu público e, extraindo indiretamente conhecimentos, noções qualitativas sobre seus alunos, intervir apreciando as diferenças, abordar e trabalhar as necessidades percebidas, as questões mais latentes para cada turma.

Se "o que fala nunca é [apenas] a palavra, o discurso, mas toda a pessoa social" (BOURDIEU, 1983, p. 14), deste modo, é importante que, a partir dessa explicitação tanto no que ela tem de hipotética, ou de verossímil, quanto no que carrega de pessoal -, o aluno consiga sofisticar seu olhar sobre si mesmo, sobre a condição social de sua família, o que dispõe enquanto privilégio, o que se lhe restringe, e exercitar a alteridade ao ouvir as histórias dos colegas, o que dá substrato para a retomada da discussão sociológica, problematizando as realidades e os pontos de vista representados.

Outros trabalhos, porém, apresentaram capturas do real que me pareceram prescindir dessa eufemização acima abordada, explorando o drama de suas personagens e testando as expectativas, de modo a construir representações cruas, pode-se dizer, 
mais verossímeis que os discursos midiáticos que invariavelmente ressaltam a história daquele que conseguiu, dos poucos vencedores; como também, a partir de tais "vivências" discursivas, superar em empiria o que pode pretender uma exposição sociológica sobre o conceito de meritocracia, por exemplo. A seguir, serão expostos alguns trechos.

O ensino médio não foi nada fácil, sempre fui bolsista em uma boa escola e graças a esse fato eu tinha a obrigação de me sobressair dentre os outros alunos, não somente nas notas, mas sempre precisei chegar pontualmente, não aprontar nada durante e nem depois das aulas. [...] foi assim, sozinha e despreparada que mergulhei de cabeça na prova e consegui ficar na lista de espera para o curso que sempre quis fazer: odontologia. Depois de dois meses fui chamada, mas infelizmente meu tempo no curso foi curto e cruel. Eu não tinha condições financeiras para comprar todos os materiais necessários para concluir, por isso abandonei ainda no primeiro semestre. [...] Hoje, observando tudo ao meu redor, me vem à cabeça somente uma coisa: como poderia ter sido a minha vida. Como seria ela agora se ao invés de largar o curso de odontologia eu fosse um dos meus colegas e conseguisse terminá-lo, como seria trabalhar nos melhores consultórios odontológicos do país, como seria ser a dona ao invés da humilde secretária, que agora já com seus 46 anos não têm mais condições de fazer nenhum curso, que tem uma família para sustentar, crianças para educar e acima de tudo dar o seu melhor para que elas tenham um futuro diferente do da mãe (Estudante C. N.).

João da Silva é um adolescente de classe baixa que acaba de terminar seu ensino médio. Sua escola não ofereceu uma boa estrutura para a formação educacional e ele teve que sustentar sua família desde os 16 anos, já que seu pai ninguém sabe quem é e sua mãe tem ele e mais cinco irmãos. Quando pequeno sonhava em ser jogador de futebol [...] trabalha numa rede de fastfood como atendente, na qual ele fica 12 horas por dia. [...] Hoje, aos quarenta e seis anos, trabalha como porteiro em um prédio, ele trabalha para sobreviver e não para viver, e chora ao se lembrar de seus sonhos de criança (Estudante P. H.).

\section{A escrita dos escritores}

Em A Economia das Trocas Linguísticas, Pierre Bourdieu esclarece a relação entre as condições de produção de um discurso mais ou menos sofisticado e a posição do interlocutor na escala social. De acordo com o autor, tanto quanto a formação do gosto artístico, problematizada em Amor pela Arte (BOURDIEU, 2003), as competências linguísticas, que não são reconhecidas enquanto resultantes de um aprendizado, mas atribuídas ao dom inato, reproduzem dissimuladamente as diferenças de classe (BOURDIEU, 1983, p. 16).

Ao considerar-se a origem social dos estudantes do Colégio de Aplicação a partir da pesquisa da realidade escolar, na turma em que estagiei, sendo os alunos 
pertencentes às classes média e média baixa, assim como os da rede pública de ensino básico que, é sabido, são em grande parte oriundos de famílias de baixa renda, há de se ponderar acerca dos limites deste trabalho: quem pode escrever assim? Quem tem o domínio da linguagem para manipulá-la e construir representações que se contraponham às representações hegemônicas, o que também subentende que se tenha capacidade de lhes reconhecer enquanto ilegítimas, interessadas e opressoras?

O que durante a redação deste trabalho surgiu como uma debilidade, acusando nossas ideias de pretenderem realizar tão somente outra forma de violência simbólica na experiência escolar dos estudantes, contribuiu para que eu lançasse um novo olhar sobre o projeto, reconhecendo que é de fato o que ele intenta desempenhar, outra violência simbólica, mas não de modo a criar uma falsa consciência, ou de impor uma verdade científica, pelo contrário, estimulando um alargamento de significados, categorias e sentidos, um processo certamente doloroso de expansão e aprimoramento das habilidades discursivas, da complexidade e do repertório linguístico.

$\mathrm{O}$ anseio de proporcionar acréscimos de capital simbólico através de atividades pedagógicas que concebam tratamentos não convencionais da língua não quer impor mais disciplina, mas compensar disparidades (SAVIANI, 1983) que escapam aos domínios da escola - de acordo com Bourdieu, sobretudo quanto ao nível e à abrangência da língua falada em casa.

Existe todo um aspecto da linguagem de autoridade que não tem senão a
função de relembrar essa autoridade e de remeter à crença que ela exige [...].
Neste caso, a estilística da linguagem é um elemento do "aparelho" (no
sentido de Pascal) que tem por função produzir ou manter a fé na linguagem.
A linguagem de autoridade deve parte importante de suas propriedades ao
fato de que precisa contribuir para sua própria credibilidade - por exemplo, a
"escrita" dos escritores, as referências e o instrumental dos eruditos, as
estatísticas dos sociólogos etc (BOURDIEU, 1983, p. 8).

É interessante notar que, se para serenar suas potencialidades transgressoras, a ficção e o discurso poético foram, desde a antiguidade, relegados à condição de adereço, de enfeite dispensável, como nos elucida Costa Lima, em Bourdieu, no entanto, vemos explicitado o poder que o estilo encerra no texto, o elemento de distinção subjacente ao discurso arrojado, desenvolto. Embora tenha elogiado a escrita ficcional, este estudo não se desviará do imperativo de reconhecer que o que pretende ensinar é também um instrumento de poder, tal como o discurso científico e a autoridade com que ele se emoldura, porém, com o proveito, que acreditamos legítimo, de se transferir poder para 
os que não detêm. A liberdade de subtrair-se à aporia da linguagem científica significa a posse de um poder superior àquele que a ciência confere aos seus súditos e praticantes, pois esta esquiva, para ser autêntica, adequada, bem colocada, supõe o domínio socialmente reconhecido desse discurso, para só então transcendê-lo e daí estar apto a jogar com ele.

[...] a crítica sociológica submete os conceitos linguísticos a um tríplice deslocamento, substituindo: a noção de gramaticalidade pela de aceitabilidade ou, se quisermos, a noção de língua pela noção de língua legítima; as relações de comunicação (ou de interação simbólica) pelas relações de força simbólica e, ao mesmo tempo, a questão do sentido do discurso pela questão do valor e do poder do discurso; enfim e correlativamente, a competência propriamente linguística pelo capital simbólico, inseparável da posição de locutor na estrutura social (BOURDIEU, 1983, p. 2).

Ao incidir sobre as carências na formação linguística, essa recriação do mundo, essa apropriação insubordinada de outros saberes que a ficção proporciona, no que logra êxito em gerar capital simbólico, tem qualquer coisa de libertária. Contudo, não posso fazer tal afirmação sem esbarrar no ceticismo desses franceses que constituem a estrutura interpretativa do meu trabalho:

\footnotetext{
O que é afinal um sistema de ensino senão uma ritualização da palavra; senão uma qualificação e uma fixação dos papeis para os sujeitos que falam; senão a constituição de um grupo doutrinário ao menos difuso; senão uma distribuição e uma apropriação do discurso com seus poderes e seus saberes? Que é uma 'escritura' (a dos escritores) senão um sistema semelhante de sujeição, que toma formas um pouco diferentes, mas cujos grandes planos são análogos? (FOUCAULT, 1996, p. 44-45).
}

Sou obrigado a discordar deste mestre, pois, que há de fato uma ritualização da palavra há; que essa escritura constitui um saber mais distinto, mais refinado, engendrando, portanto, poder e sujeição, fato; porém, se no contexto europeu, de onde se originam tais críticas, o ensino é universalizado, no Brasil, a questão é anterior: ter ou não acesso. Em comparação com as práticas discursivas que regem a nossa educação e as suas consequências - a reprodução acrítica e anônima de noções prontas -, não posso deixar de reconhecer as potências de subversão da ordem presentes no texto ficcional.

Sem pretender "fabricar" escritores - nem sociólogos - mas promover uma formação mais ampla, de modo a agregar capitais a quem não lhes dispõe, o ensinamento que busca aproximar jovens dessa "escrita dos escritores" não é uma rendição a um modelo discursivo, posto que ela não carece de ser bonita, ou 
elegantemente disposta, podendo perfeitamente ser feia, crua, ou visceral - como é adjetivada frequentemente a literatura de Charles Bukowski. É uma cara superação de modelos vigentes que, embora ainda impregnada de normas, como a gramática, de poderes simbólicos, como o discurso científico, o midiático e a distância do saber culto, de estruturas objetivas e pesadas, tal qual a inumana distribuição de capitais; em seus efeitos, pouco tem de fictícia, e talvez nem tanto de real, mas muito de uma verossímil tomada de conhecimento, representando, senão fuga, rebelião, ao mínimo, uma festa na cadeia.

\section{Considerações finais}

$\mathrm{Na}$ esperança deste método ser socializado, penso que o potencial profanador da ficção, frente a outras estratégias disciplinares, pode enriquecer e elevar discussões em temas variados, por exemplo, sobre gênero, promovendo a invenção de situações em que os sexos sejam invertidos, em que os estudantes, a partir da mimesis, possam manusear e questionar significações prévias, imagens tradicionais, noções sociológicas e experiências próprias, reconstruindo o seu posicionamento; como também para problematizar questões como a ideia de que haveria, no Brasil, uma democracia racial, explorando o tema racismo por meio de vivências discursivas. Trabalho e exploração, movimentos sociais, participação política, relativismo cultural, pós-colonialismo muitas temáticas são passíveis de serem exploradas pelos “contos sociológicos”, assim como o seu exercício pode ser adaptado e funcionar em outros níveis de ensino, como o fundamental ou o superior.

Considerando a realidade da rede pública de ensino, principalmente quanto às escolas situadas em bairros periféricos, é imperativa a abertura do campo da sociologia, a democratização de seu acesso. Isto não significa torná-la pobre para distribuí-la aos pobres, tampouco reduzi-la à opinião de cada um. Fazer sociologia no ensino médio por meio da ficção é permitir que se a pronuncie a partir da língua que se fala, do contexto em que se vive e das ferramentas de que se dispõe, é dar agência, através da representação mimética, para que se conteste a estrutura, a hegemonia das narrativas que inauguram o mundo - um mundo que talvez não corresponda à realidade dos alunos, mas que incide sobre ela, depositando discursos enganosos, reproduzindo e robustecendo ficções sociais. Em educação, há muito é consenso que a pesquisa deve 
estar associada à docência e à aprendizagem, pois então admitamos nós, professores, que se escave e vasculhe a consciência, as emoções, os sentidos, o senso comum, as ciências e as artes e incentivemos que se aprenda enquanto se expresse - quem sabe, ao final, não percebemos que o ensino pode ser uma experiência reveladora?

O discurso midiático que nos colore as mazelas do capitalismo é refrigerante, xarope gaseificado explodindo açúcar, e a ciência é engolida como um remédio do qual não se compreende a bula, para curar o mal da ignorância, e embora ela mesma afirme que suculentas frutas fazem bem à saúde, tem preferência por nos oferecer a vitamina sintetizada, fórmulas de sabedoria. Seja a partir da democratização da língua, do dom inato desmascarado em privilégio, em aprendizado, do uso pedagógico até o desgaste e a banalização daquela "escrita dos escritores", da politização através da arte, seja com metáforas baratas, enunciados científicos, professores de sociologia, português, história, física, filosofias alternativas, tutoriais no Youtube, a astrologia ou a ocupação das escolas em São Paulo, alguém ou alguma coisa há de nos ensinar que não podemos separar a cabeça pensante do resto do corpo, nem a escola da complexidade da vida social, e que, se as palavras têm sabor e o saber também alimenta, há muito mais nutrientes no conhecimento integral.

\section{Referências}

ADORNO, Theodor. O ensaio como forma. In: . Notas de Literatura I.

Tradução de Jorge de Almeida, Editora 34, Coleção Espírito Crítico, 2003.

BARTHES, Roland. Aula. Tradução de Leyla Perrone-Moisés. São Paulo: Editora Cultrix, 1978.

BOURDIEU, Pierre. A Economia das Trocas Linguísticas. In: ORTIZ, Renato (org.). Bourdieu - Sociologia. São Paulo: Ática. Coleção Grandes Cientistas Sociais, vol. 39, p.156-183, 1983.

BOURDIEU, Pierre. O Poder Simbólico. Tradução de Fernando Tomaz. Rio de Janeiro: Editora Bertrand Brasil, 1989.

BOURDIEU, Pierre. Lições da Aula. Tradução de Egon de Oliveira Rangel. São Paulo: Editora Ática, 1994. 
BOURDIEU, Pierre; DARBEL, Alain. $O$ amor pela arte: os museus de arte na Europa e seu público. São Paulo: Editora da Universidade de São Paulo: Zouk, 2003.

CANDIDO, Antonio. A personagem do romance. In: A personagem de ficção, São Paulo: Ed. Perspectiva, 1976.

ESCOBAR, Arturo. Sentipensar con la tierra. Nuevas lecturas sobre desarrollo, territorio y diferencia. Medellín: Ediciones UNAULA, 2014.

FOUCAULT, Michel. A ordem do discurso. Tradução de Laura Fraga de Almeida Sampaio. São Paulo: Edições Loyola, 1996.

FREIRE, Paulo. Pedagogia da autonomia: saberes necessários à prática educativa. São Paulo: Paz e Terra, 2011.

LIMA, Luiz Costa. Vida e mimesis. Rio de Janeiro: Editora 34, 1995.

LIMA, Luiz Costa. História. Ficção. Literatura. São Paulo: Companhia das Letras, 2006.

MILLS, Wright. A imaginação sociológica. $3^{\text {a }}$ ed. Trad. de W. Dutra. Rio de Janeiro: Zahar, 1972.

OLIVEIRA, Marta Kohl de. Vygotsky: Aprendizado e desenvolvimento: um processo sócio-histórico. São Paulo: Scipione, 1997.

RUIZ, João Álvaro. Metodologia científica: guia para eficiência nos estudos. $2^{\mathrm{a}}$ ed. São Paulo: Atlas, 1986.

SAVIANI, D. Escola e democracia. 39ª ed. Campinas, SP: Autores Associados, 1983.

WHITE, Hayden. Trópicos do Discurso: Ensaios sobre a Crítica da Cultura. Tradução de Alípio Correia de Franca Neto. $2^{a}$ ed. São Paulo: Editora da Universidade de São Paulo, 2001. 